\title{
The effects of streptozotocin-induced diabetes on ghrelin expression in rat testis: biochemical and immunohistochemical study
}

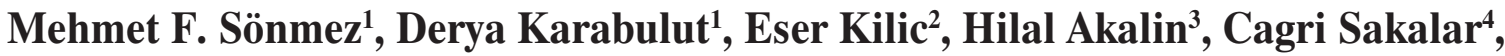 \\ Yusuf Gunduz ${ }^{1}$, Ayça Kara1, Munis Dundar ${ }^{3}$
}

${ }^{1}$ Erciyes University, Faculty of Medicine, Department of Histology and Embryology, Kayseri, Turkey

${ }^{2}$ Erciyes University, Faculty of Medicine, Department of Medical Biochemistry, Kayseri, Turkey

${ }^{3}$ Erciyes University, Faculty of Medicine, Department of Medical Genetics, Kayseri, Turkey

${ }^{4}$ Erciyes University, Faculty of Medicine, Department of Medical Biology, Kayseri, Turkey

\begin{abstract}
Introduction. Ghrelin is a hormone which has effects on the secretion of growth hormone, gastrointestinal system, cardiovascular system, cell proliferation and reproductive system. The present study we focused on the relation between ghrelin and GHS-R1a gene expression and the regulation of their expression in the testes of diabetic rats. Material and methods. 40 male Wistar albino rats were divided into four groups: control, and sampled 4, 8 and 12 weeks after induction of diabetes by streptozotocin (STZ) intraperitoneal injection ( $40 \mathrm{mg} / \mathrm{kg}$ ). The rats were decapitated under ketamine anesthesia and their testes were removed. Blood was obtained from heart and serum follicle stimulating hormone (FSH), luteinizing hormone (LH), and testosterone levels were measured by ELISA. Tissue ghrelin and GHS-R mRNA levels were determined by qRT-PCR, while ghrelin protein expression was studied by immunohistochemistry. Histopathological damage scores were also assessed.

Results. Eight weeks after diabetes induction serum FSH level was increased, whereas LH and testosterone concentrations decreased. The ghrelin and GHS-R1a gene expression and ghrelin immunohistochemistry score first tended to increase after first four weeks of diabetes, and then tended to decrease. Ghrelin-immunopositive cells were detected in Leydig cells in all groups of rats, however, not in the germinal epithelium. Congestion of vessels and hemorrhage, formation of the vacuoles in spermatogonia and spermatocytes, desquamation of spermatids in the lumen and disorganization of seminiferous tubule germinal epithelium were observed in testis of all the diabetic rats. In addition, mean testicular biopsy score and mean seminiferous tubule diameter were getting lower in diabetic animals.

Conclusion. Our results suggest that diabetes affects ghrelin expression in rat testis. (Folia Histochemica et Cytobiologica 2015, Vol. 53, No. 1, 26-34)
\end{abstract}

Key words: streptozotocin diabetes; rat; testis; ghrelin; gonadotropins; IHC; RT-PCR

Correspondence address: Assoc. Prof. M.F. Sönmez, M.D.

Department of Histology and Embryology

Faculty of Medicine, Erciyes University

38039 Kayseri, Turkey

tel.: +90 35243749 01/23356, fax: +90 3524375285

e-mail: drmfatihsonmez@hotmail.com,

mfsonmez@erciyes.edu.tr

\section{Introduction}

Ghrelin is a 28 -amino-acid peptide with an essential serine 3 n-octanoylation [1]. Ghrelin is the natural ligand of the growth hormone secretagogue receptor (GHS-R), and was first found to induce GH secretion in various species [2-4]. Ghrelin has been primarily detected in the A-cells of stomach, however, both ghrelin and the GHS-R are also expressed in a large 
spectrum of tissues including brain, kidney, pancreas, uterus and testis [5-7]. It was found that ghrelin is then only peripheral hormone which stimulates food intake by acting in hypothalamus and is involved in multiple endocrine and non-endocrine processes such as metabolic and cardiovascular effects, regulation of gastric motility and acid secretion, regulation of glucose metabolism and insulin secretion and modulation of cell proliferation [8-9].

Accumulated evidence suggests that ghrelin may play a role in the regulation of reproductive processes. Circulating ghrelin has been found to affect gonadotropin releasing hormone (GnRH), follicle stimulating hormone (FSH) and luteinizing hormone (LH) serum levels and as a result to act on rat hypothalamic-pituitary gonadal axis (HPGA) [10-11]. Also, it has been shown that ghrelin and its functional receptor are expressed in reproductive organs such as ovary, uterus, prostate, and testes [11-13]. This pattern of expression implies that ghrelin produced by certain organs (i.e. testes, prostate) may be involved with regulatory functions in distinct tissues [14].

Diabetes mellitus (DM) interferes with male fertility on many levels. Endocrine controls of spermatogenesis, penile erection, and pubertal initiation are all affected, in addition to ejaculation distortion [15-16]. Many studies of diabetic men have demonstrated pathologic changes in sperm count, motility and morphology [17-18]. Furthermore, it has been demonstrated that STZ-induced diabetic rats have increased plasma ghrelin levels and gastric preproghrelin mRNA expression levels [19]. No studies, however, have addressed the expression of ghrelin in diabetic rat's testis. The present study focused on the relation between ghrelin and its receptor and the regulation of their expression in rats with STZ-induced DM by Enzyme-Linked ImmunoSorbent Assay (ELISA), Real-Time Polymerase Chain Reaction (RT-PCR), and immunohistochemistry.

\section{Material and methods}

Animals. Sexually mature male Wistar rats obtained from the Hakan Çetinsaya Experimental and Clinic Research Center, Erciyes University, Kayseri, Turkey, were used for this study. They were housed in plastic cages in a well-ventilated rat house and allowed ad libitum access to food and water and kept at 12-h light: dark cycle. All the animals received humane care according to the standard guidelines. Ethical approval for study was obtained from Erciyes University Animal Researches Local Ethics Committee and the ethic regulations have been followed in accordance with national and institutional guidelines. The rats were randomly assigned to four groups of ten rats per group. Group 1 (control): served as control; Group 2: four weeks diabetic rats; Group 3: eight weeks diabetic rats; Group 4: twelve weeks diabetic rats.

Induction of diabetes and tissue sampling. Diabetes was induced in 12-week-old male Wistar rats by intraperitoneal injection of STZ $(40 \mathrm{mg} / \mathrm{kg})(\mathrm{Sc}-200719$, Santa Cruz Biotechnology, CA, USA) after an overnight fast $(\mathrm{n}=30)$; control rats were injected with physiological saline $(\mathrm{n}=10)$. Hyperglycemia was confirmed $72 \mathrm{~h}$ after streptozotocin injection by measuring glucose levels in the blood obtained from the tail vein, using a glucometer. Animals having mean plasma glucose levels higher than $250 \mathrm{mg} / \mathrm{dL}$ were considered diabetic. Glycemia was also checked at sacrifice at 4 , 8 or 12 weeks after streptozotocin injection.

At the end of experimental period, animals were killed by decapitation under intraperitoneal ketamine $(75 \mathrm{mg} / \mathrm{kg})+$ xylazine $(10 \mathrm{mg} / \mathrm{kg})$ anesthesia. Blood samples were taken from the heart for biochemical determinations. After decapitation, both testes tissues were quickly removed and testes were weighed. Some of the testes tissues were used for qRT-PCR analyses and the other tissues were fixed in Bouin's fixative for histological examination.

Measurements of serum hormone concentrations. Serum testosterone level was measured by ELISA method using CUSABIO Rat Testosterone (T) Elisa kit (ELISA CSB-E05100r, 96 Wells kit, CUSABIO Brotech CO., LTD, Whuan, Hubei, P.R. China) according to the kit protocol. The sensitivity of the kit was $0.06-25.6 \mathrm{ng} / \mathrm{mL}$.

Serum FSH level was measured by ELISA method using CUSABIO Rat Follicle-Stimulating Hormone (FSH) Elisa kit (ELISA CSB-E06869r, 96 Wells kit, CUSABIO Brotech CO., LTD, Whuan, Hubei, P.R. China) according to the kit protocol. The sensitivity of the kit was $0.4-100 \mathrm{mlU} / \mathrm{mL}$. Serum LH level was measured by ELISA method using CUSABIO Rat Luteinizing Hormone (LH) Elisa kit (ELISA CSB-E12654r, 96 Wells kit, CUSABIO Biotech CO., LTD, Whuan, Hubei, P.R. China) according to the kit protocol. The sensitivity of the kit was $0.15-60 \mathrm{mlU} / \mathrm{mL}$.

Histopathological evaluation. The testicular tissue was examined and evaluated in blinded random order with standard light microscopy by a histologist. Three slides prepared from the upper, lower and midportions of the testes were evaluated for each testis. Mean seminiferous tubule diameter (MSTD) was measured in micrometers (Analysis LS Research Program). More than 20 seminiferous tubular sections per testis were used to determine mean tubular biopsy score (MTBS) in the range from 1 to 10 as described previously [20]. In each biopsy, 50-100 cross sections of seminiferous tubules were evaluated according to criteria presented in Table 1. 
Table 1. Mean tubular biopsy score (MTBS) for the evaluation of spermatogenesis in rat

\begin{tabular}{|c|l|}
\hline Score & Evaluation of spermatogenesis \\
\hline $\mathbf{1}$ & No cells visualized in tubular cross section \\
\hline $\mathbf{2}$ & Sertoli cells only \\
\hline $\mathbf{3}$ & Only spermatogonia present \\
\hline $\mathbf{4}$ & No sperm cells or spermatids, few spermatocytes $(<5)$ \\
\hline $\mathbf{5}$ & No sperm cells or spermatids, presence of spermatocytes \\
\hline $\mathbf{6}$ & No sperm cells, few spermatids $(<5$ to 10$)$ \\
\hline $\mathbf{7}$ & No sperm cells, presence of spermatids \\
\hline $\mathbf{8}$ & Presence of few sperm cells $(<5$ to 10$)$ \\
\hline $\mathbf{9}$ & Some sperm cells, with a disorganized epithelium \\
\hline $\mathbf{1 0}$ & Compete spermatogenesis with mature sperm cells \\
\hline
\end{tabular}

Immunohistochemistry. The expression of ghrelin was detected immunohistochemically in the testes using a rabbit polyclonal antibody (sc.50297 Santa Cruz Biotechnology, CA, USA) and the streptavidin-biotin peroxidase technique as previously described [21]. The procedure was performed under identical conditions for all sections. Paraffin sections ( $5 \mu \mathrm{m}$ thick) were deparaffinized in xylene. The sections were rehydrated, rinsed in deionized water and antigen retrieval was carried out by microwave treatment in $0.01 \mathrm{M}$ sodium citrate buffer $(\mathrm{pH} 6.0)$ at $95^{\circ} \mathrm{C}$ for $5 \mathrm{~min}$ then the slides was cooled rapidly room temperature for $20 \mathrm{~min}$. After sections washed with phosphate-buffered saline (PBS), endogenous peroxidase activity was inhibited $1 \% \mathrm{H}_{2} \mathrm{O}_{2}$ in methanol for $10 \mathrm{~min} .5 \%$ serum blocking was used to block the nonspecific staining. The histological sections were then incubated with the polyclonal antibody for ghrelin at a dilution of $5 \mu \mathrm{g} / \mathrm{mL}$ in $5 \%$ serum at $4^{\circ} \mathrm{C}$. After washing with PBS, sections were incubated with the biotinylated secondary antibodies. Then the immunoreaction was amplified with streptavidin-avidin-peroxidase complex, and the sections were visualized by using 3,3P-diaminobenzidine tetrahydrochloride (DAB) and lightly counter-stained with hematoxylin.
The histoscore of ghrelin was quantified as the density of Leydig cells stained using light microscopy (sections were photographed using an Olympus BX-51 photomicroscope, $\times 40$ objectives) and Image-J software. At least six sections and ten separate fields of each specimen were viewed. Positive and negative controls were also examined.

Quantitative RT-PCR. Total RNA was isolated from the 20-30 mg testis tissues using MO Bio kit (MO Bio, Solana Beach, CA, USA cat.: 15000-50) following the manufacturer's protocol. Reverse transcription was performed using hexamer and oligo-dT primers and Transcriptor High Fidelity Reverse Transcriptase (Roche, REF: 05081955001; Version 6.0) following the manufacturer's protocol (1 $\mu \mathrm{g}$ of isolated RNA per reaction). The acquired cDNA was subjected to quantitative RT-PCR reaction using LightCycler $^{\circledR}$ 480 Probes Master (Roche, REF: 04707494001; Version 09) and detected with Universal ProbeLibrary Probes (Roche, Applied Sciences, Manheim, Germany) for the ghrelin, ghrelin receptor and housekeeping genes (Table 2). UPL probes are labeled at the 5' end with fluorescein (FAM) and at the 3' end with a dark quencher dye. UPL assays are compatible with all real-time PCR instruments capable of detecting fluorescein (FAM) or SYBR Green I. The probes for ghrelin and ghrelin receptor were labeled with the FAM dye. Amplification of rat glyceraldehyde-3-phosphate dehydrogenase (GAPDH) was used as housekeeping/reference gene for the quality and endogenous normalization of the RNA samples investigated. The GAPDH was labeled with FAM dye, so that amplifications were carried out in the same reactions as ghrelin or GHSR amplification. Reaction was conducted on LightCycler ${ }^{\circledR} 480$ II (Roche) in 45 cycles and reaction results was analyzed via Efficiency corrected Advanced Relative Quantification algorithm on LightCycler ${ }^{\circledR} 480$ SW 1.5 software. Conditions of the reaction were as follows: denaturation $95^{\circ} \mathrm{C} 5 \mathrm{~min}$, annealing of primers $50^{\circ} \mathrm{C} 15 \mathrm{sec}$, elongation $72^{\circ} \mathrm{C} 10 \mathrm{sec}$. All samples were tested in duplicate.

Statistical analysis. One-way analysis of variance (ANOVA) and post hoc Tukey test were used to determine differences

Table 2. Sequences of primers and ID numbers of UPL probes used for qRT-PCR

\begin{tabular}{|c|c|c|c|c|c|c|}
\hline Organism & $\begin{array}{l}\text { Gene } \\
\text { symbol }\end{array}$ & Gene description & Assay ID & $\begin{array}{l}\text { Forward primer } \\
\text { sequence }\end{array}$ & $\begin{array}{l}\text { Reverse primer } \\
\text { sequence }\end{array}$ & $\begin{array}{l}\text { UPL } \\
\text { probe } \\
\text { no. }\end{array}$ \\
\hline Rattus norvegicus & GapdH & $\begin{array}{l}\text { Glyceraldehyde-3-phosphate } \\
\text { dehydrogenase }\end{array}$ & 502303 & $\begin{array}{l}\text { AAAGCTGTGGCG- } \\
\text { TGATGG }\end{array}$ & $\begin{array}{l}\text { TTCAGCTC- } \\
\text { TGGGAT- } \\
\text { GACCTT }\end{array}$ & 26 \\
\hline Rattus norvegicus & Ghrl & $\begin{array}{l}\text { Appetite-regulating hormone } \\
\text { precursor (growth hormone } \\
\text { secretagogue) }\end{array}$ & 503935 & $\begin{array}{l}\text { GGAGGAGCTG- } \\
\text { GAAATCAGGT }\end{array}$ & $\begin{array}{l}\text { GCTGGTAC- } \\
\text { TGAGCTCCT- } \\
\text { GACA }\end{array}$ & 148 \\
\hline Rattus norvegicus & Ghsr & $\begin{array}{l}\text { Growth hormone secretagogue } \\
\text { receptor type } 1 \text { (GHS-R) }\end{array}$ & 503831 & $\begin{array}{l}\text { CCAGAACCACA- } \\
\text { AGCAGACAG }\end{array}$ & $\begin{array}{l}\text { CGAAG- } \\
\text { GACTTGGA- } \\
\text { AAAGAGGT }\end{array}$ & 71 \\
\hline
\end{tabular}


Table 3. Blood glucose, body weight, testicular weight, mean seminiferous tubule diameter (MSTD) and Johnsen-like score of control and diabetic rats

\begin{tabular}{|l|c|c|c|c|c|}
\hline & $\begin{array}{c}\text { Body weight } \\
{[\mathbf{g}]}\end{array}$ & $\begin{array}{c}\text { Testis weight } \\
\text { (average of both) }[\mathbf{g}]\end{array}$ & $\begin{array}{c}\text { Serum glucose } \\
{[\mathbf{m g} / \mathbf{d L}]}\end{array}$ & $\begin{array}{c}\text { Johnsen-like } \\
\text { score }\end{array}$ & $\begin{array}{c}\text { MSTD } \\
{[\mu \mathbf{m}]}\end{array}$ \\
\hline Control, untreated rats & $286.1 \pm 13.6$ & $1.34 \pm 0.23$ & $106.10 \pm 2.51$ & $9.46 \pm 0.07$ & $387.36 \pm 6.25$ \\
\hline $\begin{array}{l}\text { Four weeks after STZ } \\
\text { administration }\end{array}$ & $269.9 \pm 8.6$ & $1.18 \pm 0.37$ & $485.90 \pm 36.07^{*}$ & $8.21 \pm 0.33^{*}$ & $323.79 \pm 6.65^{* *}$ \\
\hline $\begin{array}{l}\text { Eight weeks after STZ } \\
\text { administration }\end{array}$ & $169.6 \pm 15.5^{*}$ & $0.85 \pm 0.73^{*}$ & $509.10 \pm 32.86^{*}$ & $6.83 \pm 0.37^{* *}$ & $287.12 \pm 9.84^{* *}$ \\
\hline $\begin{array}{l}\text { Twelve weeks after } \\
\text { STZ administration }\end{array}$ & $203.2 \pm 13.7^{*}$ & $0.98 \pm 0.62^{*}$ & $453.71 \pm 30.61^{*}$ & $5.58 \pm 0.44^{* *}$ & $268.20 \pm 11.67^{* *}$ \\
\hline
\end{tabular}

Values are expressed as mean \pm standard error. ${ }^{*},{ }^{*}$ *significantly different from control rats, $\mathrm{p}<0.05$ and $\mathrm{p}<0.001$, respectively

between groups. Results are presented as mean \pm SEM. Values were considered statistically significant if $\mathrm{p}<0.05$. The SPSS/PC program (Version 15.0; SPSS, Chicago, IL) was used for the statistical analysis.

\section{Results}

\section{Serum concentrations of glucose and hormones}

At the end of 4-, 8- and 12-week periods, serum glucose levels in STZ-treated rats were significantly higher than in control animals (Table 2). The initial body weights of all groups were similar. However, final body weights and testis weights (average of both testes) of eight and twelve week's diabetic animals were significantly reduced when compared to control animals (Table 3 ).

The changes in serum FSH, LH and testosterone levels are shown in Figure 1. After 8 weeks from the induction of diabetes serum FSH level of diabetic rats was higher than that of control rats, however, the differences were not statistically significant after four weeks and twelve weeks from STZ administration. Serum LH and testosterone concentrations were significantly decreased compared to control rats eight and twelve weeks after diabetes induction.

\section{Histopathological findings}

Control testes, showed the presence of normal testicular architecture and regular seminiferous tubular morphology with normal spermatogenesis and the presence of primary and secondary spermatocytes, spermatids, and spermatozoa (Figure 2A). Congestion of vessels and hemorrhage, formation of the vacuoles in epithelial cells, desquamation of epithelial cells in the lumen, disorder of seminiferous tubule germinal epithelium were observed in diabetic rats (group II, Figure 2B). Eight (Figure 2C) and twelve weeks (Figure 2D) after diabetes induction, in addition to these findings, multinucleated giant cells and necrosis of some seminiferous tubules were found.

The MSTD and Johnsen-like score values for testes in each group are shown in Table 2. It was observed that the MSTD and MTBS values of STZ-induced diabetic rats' testes were statistically significantly lower than the MSTD and MTBS values of control rats' testes. MSTD and MTBS became lower 8 and 12 weeks after induction of diabetes.

\section{Immunohistochemical findings}

The patterns of cellular expression of ghrelin protein were assessed by immunohistochemistry in the testes of each group of rats. Ghrelin-immunopositive cells were detected in Leydig cells in all groups of rats, however, not in the germinal epithelium (Figure 3). Histoscore for the ghrelin immunoexpression in the testes was quantified using Image-J software. The percentage staining expression of ghrelin (mean \pm SE) was similar in the all groups (Figure 4).

\section{qRT-PCR findings}

Ghrelin and ghrelin receptor mRNA expression levels in testes were quantified using qRT-PCR. The tendency to increased levels of ghrelin and GHS-R mRNA was observed four-weeks after induction of diabetes followed by tendency to decrease mRNA levels eight and twelve-weeks after streptozotocin administration. However, the differences in the expression levels of both mRNAs were not significant (Figure 4).

\section{Discussion}

The growing evidence has demonstrated the connectivity between the mechanisms controlling the energy homoeostasis and the reproductive function [22]. 

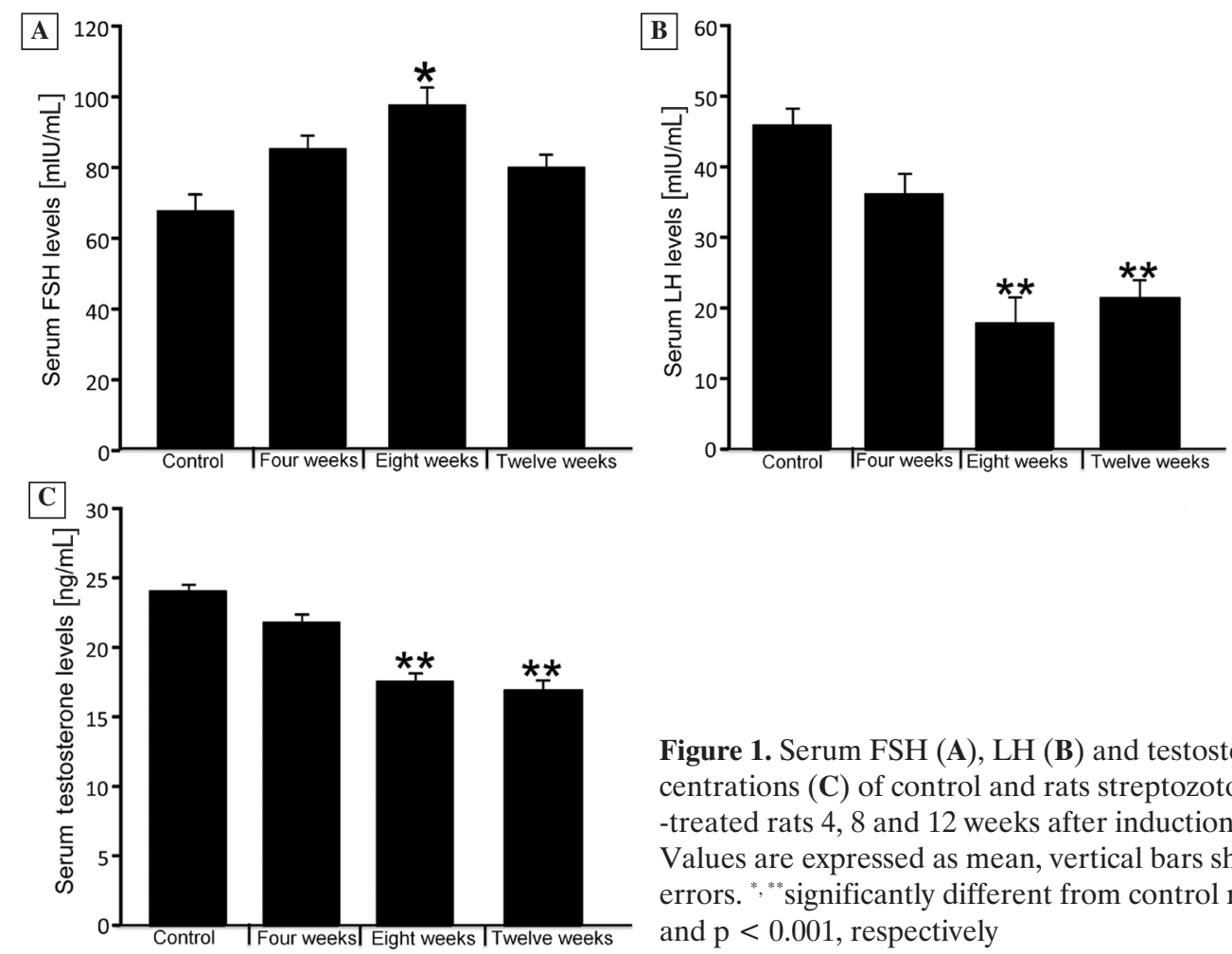

Figure 1. Serum FSH (A), LH (B) and testosterone concentrations $(\mathbf{C})$ of control and rats streptozotocin (STZ) -treated rats 4, 8 and 12 weeks after induction of diabetes. Values are expressed as mean, vertical bars show standard errors. ", "* significantly different from control rats, $p<0.05$ and $\mathrm{p}<0.001$, respectively

Expression of ghrelin has been shown in mature Leydig cells of rat and human. Therefore, expression of the functional ghrelin receptor, the GHS-R type 1a, has been demonstrated in Sertoli and Leydig cells $[11,23]$. On the other hand, GHS-R1a produced in the seminiferous tubules suggests that ghrelin may play a regulatory role by targeting the seminiferous epithelium [23]. Ghrelin has been thought to regulate reproduction by modulating the levels of factors released from the brain and pituitary [24]. Daily supply of ghrelin for 10 days resulted in a reduce in non-spermatogonial cells, seminiferous tubule diameter and germinal epithelium thickness [25]. This pattern suggests an inhibitory role for ghrelin on testis. Injections of ghrelin into testis blocked the proliferation of Leydig cells. Ghrelin also reduced the production of stem cell factor both in vitro and in vivo in rats [13]. Ghrelin is likely to play a role in gonadal functions and regulation of gonadal factors [26]. In this study, expression of both ghrelin and ghrelin receptor in testes was determined. Ghrelin was observed by immunohistochemistry to be moderately expressed in Leydig cells. Observed expression of ghrelin only in Leydig cells is in accordance with previous studies [11,27].

The diabetes causes infertility in animal models. Testicular weight, sperm quantity and quality, and testosterone production were affected negatively by diabetes [28-29]. Plasma levels of ghrelin are affected by nutritional status implicating a role in regulating energy balance. Regulation of reproduction is regulated by multiple factors and the reproductive achievement is dependent on total energy load. Ghrelin has been demonstrated to positively modulate energy acquirement. Reproductive capacity is dependent on the availability of energy. In our literature search, we did not find any study focusing on the effect of diabetes on the ghrelin expression in testes. We decided to study the expression of ghrelin in testes of diabetic and control rats, because energy balance is disturbed in diabetes and ghrelin is involved in energy balance and found to be expressed in reproductive system.

STZ-induced diabetic rats are the classic diabetic model that is used in animal researches. The body weight and serum insulin levels of the STZ-treated rats decreased significantly and their blood glucose values increased. These findings suggest that the STZ injection successfully induced diabetes in our study. Diabetes mellitus has adverse effects on male sexual and reproductive functions in diabetic patients and animals [30, 31]. Decreased testosterone levels, testicular dysfunction and spermatogenic disruption in the testis have been shown in diabetic men and experimental animals, which cause erectile dysfunction and a reduced sperm motility and semen volume 


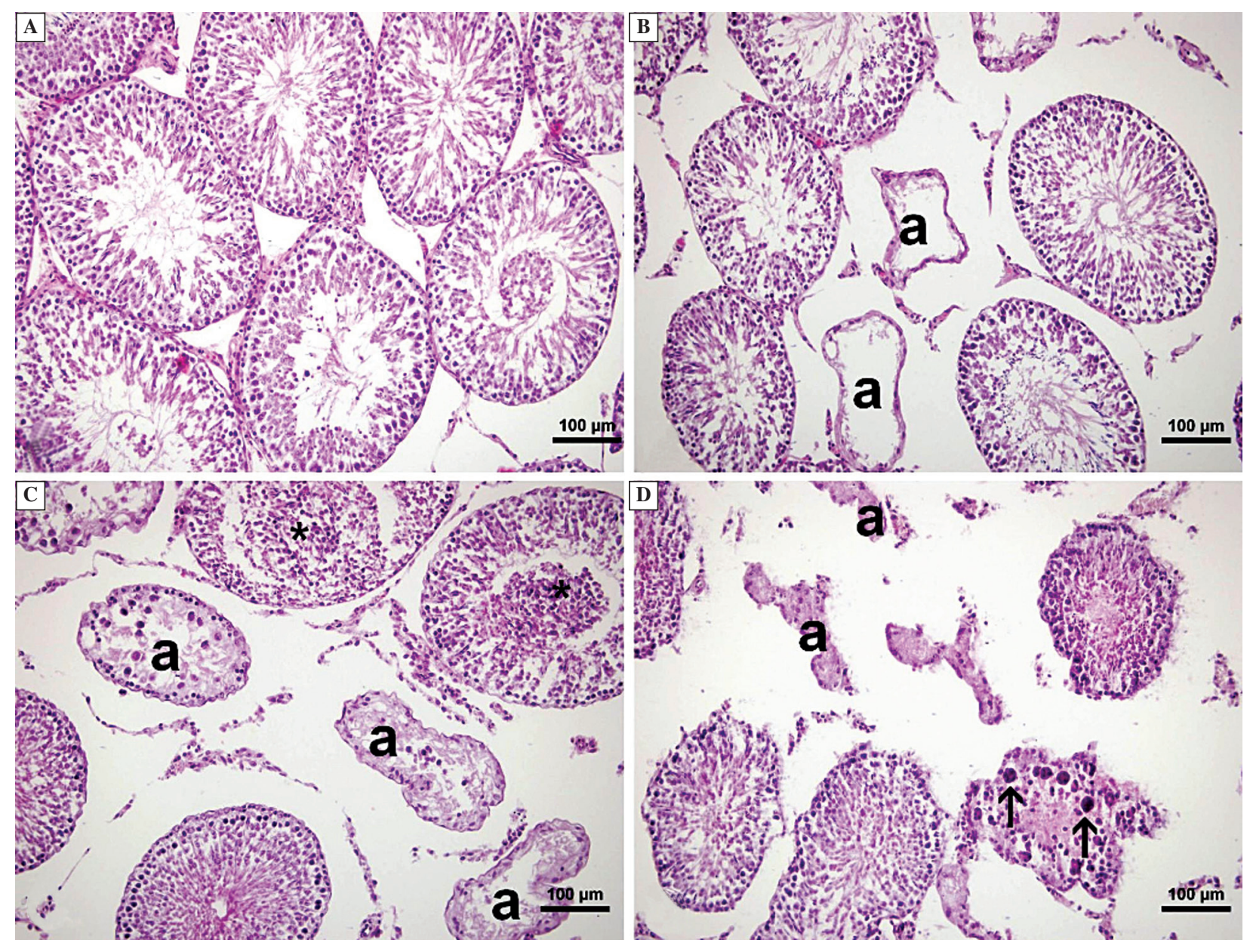

Figure 2. Structure of testis in different groups of rats. A. In controls, normal testicular architecture was observed; B. Diabetic rat, 4 weeks after streptozotocin administration: formation of the vacuoles (arrow) in germinal epithelium cells, disordered structure of germinal epithelium and atrophic seminiferous tubules (a) are visible; C. Diabetic rat, 8 weeks after induction of diabetes: desquamation of epithelial cells (asterisk) in the lumen and atrophic seminiferous tubules (a) are visible; D. Diabetic rat, 12 weeks after streptozotocin administration: multinucleated giant cells in the germinal epithelium (arrows) and atrophic seminiferous tubules (a) are visible. Section were stained with H \& E. Scale bar $=100 \mu \mathrm{m}$

[31-33]. Therefore, diabetes has a significant impact both directly and indirectly on the fertility of men with this disease [34,35]. In the testicular tissue, MTBS and MSTD are used to assess histopathological damage. In our study, serum testosterone level, MSTD and MTBS values of STZ-induced diabetic rats' testes were statistically significantly lower than the control rats' testes. These observations are in agreement with previous studies [32,36]. Therefore, MSTD and MTBS values get lower when rats are diabetic for longer periods.

There are many studies on the effect of diabetes on serum and tissue levels of ghrelin [15,37]. STZ-induced rats were found to have significantly higher serum ghrelin levels. However, in diabetic rats, changes of ghrelin levels vary in different tissues. Masaoka et al. [19] observed an increase in preproghrelin mRNA levels in the stomach of diabetic rats; on the other hand, they have not observed a difference in the duodenum and the colon. Ishii et al. [38] showed a non-significant increase in ghrelin levels in the stomach of diabetic rats. In this study, we found that the ghrelin and GHS-R1a gene expression and ghrelin immunohistochemistry score first increased in four weeks diabetic rats, then decreased in long-term diabetic rats; however, these differences were not significant. As shown in multiple studies, the diabetes affects ghrelin levels in various tissues differentially.

Several studies have pointed out the HPG axis as the target of ghrelin function [22,39-41]. However, there are conflicting data on ghrelin levels and gonadotropins levels. For example, intracerebroventricular administration of ghrelin leads to a significant inhibition of LH secretion in cyclic female rats [22]. In addition, daily injection of ghrelin during puberty similarly decreased LH levels [39]. In the other study, 


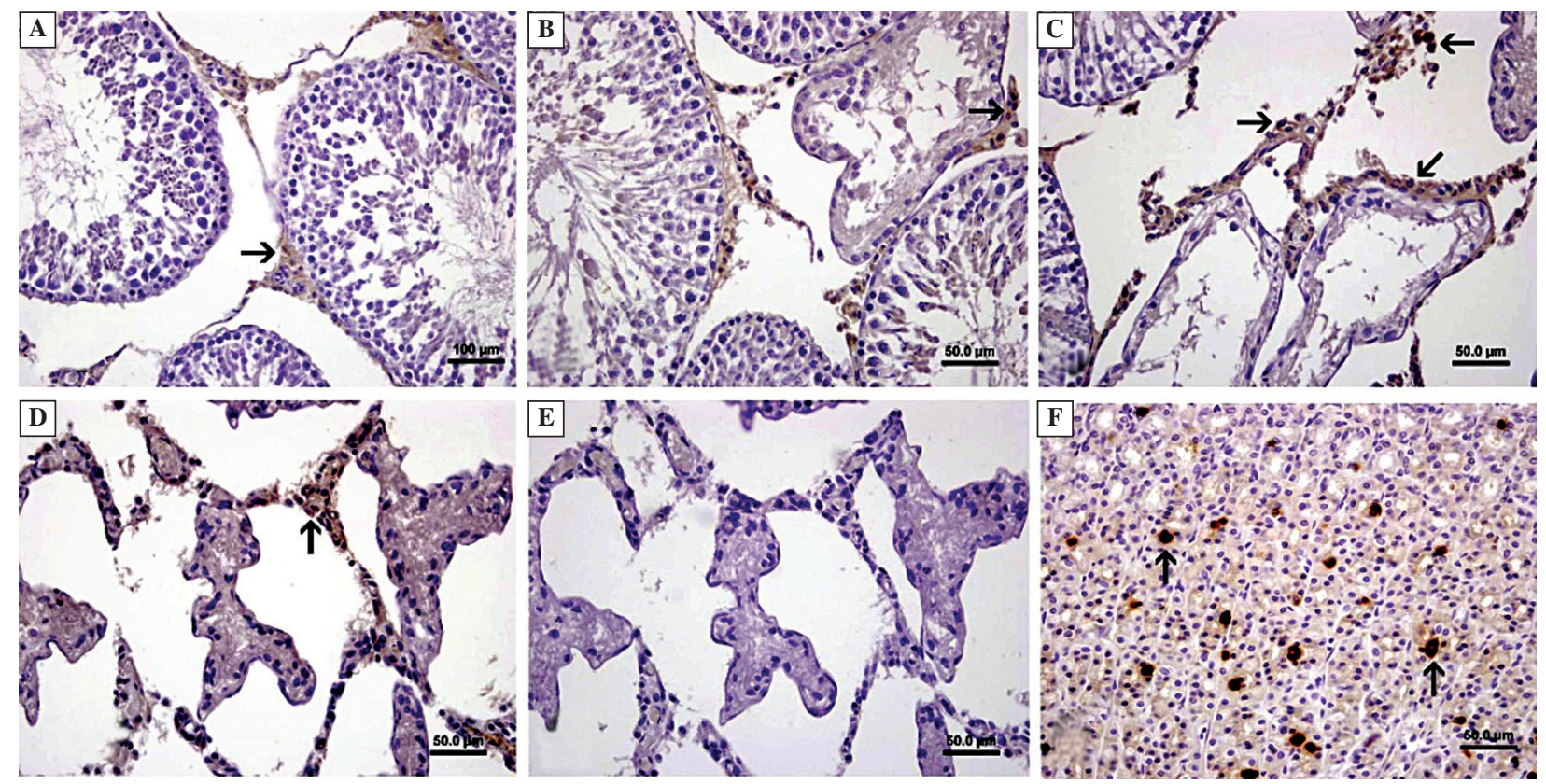

Figure 3. The effects of STZ-induced diabetes on ghrelin expression (arrows) in the testes. A. Control rat; B. Four weeks after induction of diabetes; C. Eight weeks diabetes; D. Twelve weeks diabetes; E. Negative controls after twelve weeks diabetes; F. Positive control: ghrelin-immunopositive cells in rat stomach tissue. Immunohistochemical staining was performed as described in Material and methods

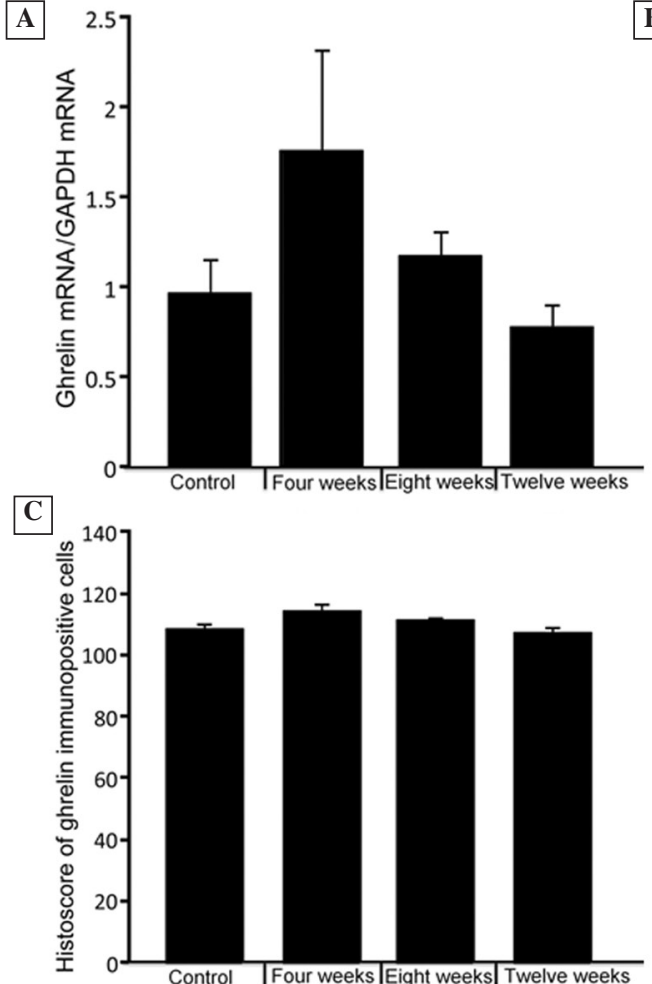

repeated ghrelin injections in food-restricted males dramatically decreased plasma LH and T concentrations and reduced testis weight [40]. Duran et al. [41]

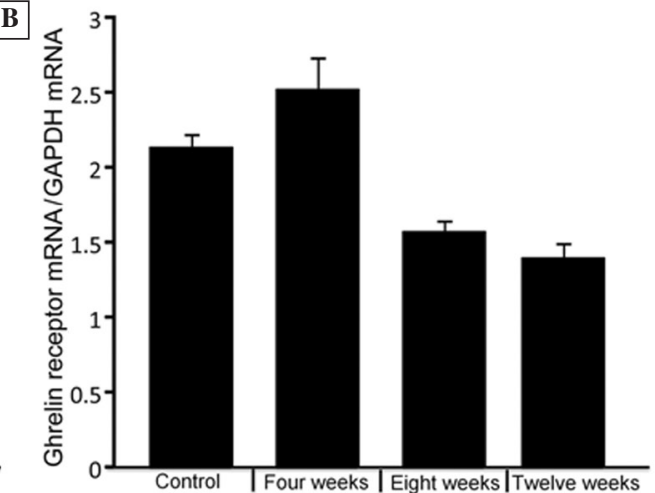

Figure 4. Ghrelin mRNA (A) and ghrelin receptor mRNA (B) levels and histoscore of ghrelin-immunopositive cells (C) in the testes of control rats and streptozotocin-treated animals four, eight and twelve weeks after induction of diabetes. mRNA were determined by QPCR as described in Material and methods. Values represent means and standard errors

demonstrated decreased serum Ghrelin levels in idiopathic hypogonadotropic hypogonadism (IHH) patients who also had lower serum LH and testoste- 
rone levels. They have recommended that low ghrelin levels in the patients with IHH could result from low levels of gonadotropins. Ilhan et al. [42] demonstrated that when the serum testosterone levels were increased, serum ghrelin level was increased significantly. Ishikawa et al. [43] demonstrated that expression of ghrelin by Leydig cells is inversely correlated with the serum $\mathrm{T}$ concentration. Also they have proposed that ghrelin has not directly related on spermatogenesis. In this study, we found that Ghrelin levels changed in the testes tissue of diabetic rats that had lowered levels of LH and testosterone because of diabetes.

In conclusion, we could say that diabetes causes morphological damage to testicular tissue and it also affects serum levels of gonadotropins. Moreover, it seems that when diabetes is being in longer duration, the damages are becoming much more clearly appeared than before. The present study also demonstrates that both ghrelin and GHS-R1a gene expression are present in control and diabetic rat testes. In this study, both serum gonadotropins and also negative energy balance caused by diabetes probably affect the ghrelin level in the testis. High levels of ghrelin in four weeks diabetic rats is probably due to the negative energy balance caused by the diabetes, however, subsequent decrease of ghrelin levels in eight and twelve diabetic rats is probably due the stronger regulatory impact of low gonadotropin serum levels on ghrelin expression in the testis. In the light of these findings, we could say that, although it is locally, ghrelin is making a clear contribution to the negative effects of diabetes in testicular tissue.

\section{Acknowledgments}

This work was supported, by a research grant from the Erciyes University Scientific Research Projects Unit (EUBAP, TSA-11-3657).

\section{References}

1. Kojima M, Hosoda H, Date $\mathrm{Y}$ et al. Ghrelin is a growth-hormone-releasing acylated peptide from stomach. Nature. 1999;402:656-660. doi: 10.1038/45230.

2. Arvat E, Maccario M, Di Vito L et al. Endocrine activities of ghrelin, a natural growth hormone secretagogue (GHS), in humans: comparison and interactions with hexarelin, a nonnatural peptidyl GHS, and GH-releasing hormone. JClin Endocrinol Metab. 2001;86:1169-1174. doi:10.1210/jcem. 86.3.7314.

3. Tschop M, Smiley DL, Heiman ML. Ghrelin induces adiposity in rodents. Nature. 2000;407:908-913. doi: 10.1038/35038090.

4. Broglio F, Arvat E, Benso A et al. Ghrelin: endocrine and non-endocrine actions. J Pediatr Endocrinol Metab. 2002;15:1219-1227. PMID: 12510973.

5. Tanaka K, Minoura H, Isobe $\mathrm{T}$ et al. Ghrelin is involved in the decidualization of human endometrial stromal cells.
J Clin Endocrinol Metab. 2003;88:2335-2340. doi: 10.1210/jc. 2002-021024.

6. Unsal F, Sönmez MF. The effects of ovariectomy on ghrelin expression in the rat uterus. Adv Clin Exp Med. 2014;23:363-370. PMID: 24979506.

7. Sönmez MF, Ozan E. Determination of ghrelin immunoreactivity in the rat stomach after fasting and refeeding. Acta Histochem. 2007;109:193-199. doi: 10.1016/j.acthis.2007. 02.002 .

8. Jeffery PL, Herington AC, Chopin LK. The potential autocrine/paracrine roles of ghrelin and its receptor in hormone-dependent cancer. Cytokine Growth Factor Rev. 2003;14:113-122. doi: 10.1016/S1359-6101(02)00089-8.

9. Fernandez-Fernandez R, Tena-Sempere M, Aguilar E, Pinilla L. Ghrelin effects on gonadotropin secretion in male and female rats. Neurosci Lett. 2004;362:103-107. doi: 10.1016/ /j.neulet.2004.03.003.

10. Lorenzi T, Meli R, Marzioni D et al. Ghrelin: a metabolic signal affecting the reproductive system. Cytokine Growth Factor Rev. 2009;20:137-152. doi: 10.1016/j.cytogfr.2009. 02.003 .

11. Tena-Sempere M, Barreiro ML, Gonzalez LC et al. Novel expression and functional role of ghrelin in rat testis. Endocrinology. 2002;143:717-725. PMID: 11796529.

12. Gaytan F, Barreiro ML, Caminos JE et al. Expression of ghrelin and its functional receptor, the type 1a growth hormone secretagogue receptor, in normal human testis and testicular tumors. J Clin Endocrinol Metab. 2004;89:400-409. doi: 10.1210/jc.2003-031375.

13. Barreiro ML, Gaytan F, Castellano JM et al. Ghrelin inhibits the proliferative activity of immature Leydig cells in vivo and regulates stem cell factor messenger ribonucleic acid expression in rat testis. Endocrinology. 2004;145:4825-4834. doi: 10.1210/en.2004-0732.

14. Ueberberg B, Unger N, Saeger W et al. Expression of ghrelin and its receptor in human tissues. Horm Metab Res. 2009;41:814-821. doi: 10.1055/s-0029-1233462.

15. La Vignera S, Condorelli R, Vicari E et al. Diabetes mellitus and sperm parameters. J Androl. 2012;33:145-153. doi: 10.2164/jandrol.111.013193.

16. Sexton WJ, Jarow JP. Effect of diabetes mellitus upon male reproductive function. Urology. 1997;49:508-513. doi: 10.1016/ /S0090-4295(96)00573-0.

17. Agbaje IM, Rogers DA, McVicar CM et al. Insulin dependant diabetes mellitus: implications for male reproductive function. Hum Reprod. 2007;22:1871-1877. doi: 10.1093/ /humrep/dem077.

18. Delfino M, Imbrogno N, Elia J et al. Prevalence of diabetes mellitus in male partners of infertile couples. Minerva Urol Nefrol. 2007;59:131-135. PMID: 17571048.

19. Masaoka T, Suzuki H, Hosoda H et al. Enhanced plasma ghrelin levels in rats with streptozotocin-induced diabetes. FEBS Lett. 2003;541:64-68. PMID: 12706820.

20. Soliman HM, Wagih HM, Attia GM et al. Light and electron microscopic study on the effect of antischizophrenic drugs on the structure of seminiferous tubules of adult male albino rats. Folia Histochem Cytobiol. 2014;52:335-349. doi: 10.5603/ /FHC.a2014.0038.

21. Bayatli F, Akkuş D, Kilic E, Saraymen R, Sönmez MF. The protective effects of grape seed extract on MDA, AOPP, apoptosis and eNOS expression in testicular torsion: an experimental study. World J Urol. 2013;31:615-622. doi: 10.1007/ /s00345-013-1049-8. 
22. Fernandez-Fernandez R, Tena-Sempere M, Navarro VM et al. Effects of ghrelin upon gonadotropin-releasing hormone and gonadotropin secretion in adult female rats: in vivo and in vitro studies. Neuroendocrinology. 2005;82:245-255. doi: $10.1159 / 000092753$.

23. Barreiro ML, Tena-Sempere M. Ghrelin and reproduction: a novel signal linking energy status and fertility? Mol Cell Endocrinol. 2004;226:1-9. doi: 10.1016/j.mce.2004.07.015.

24. Tena-Sempere M. Ghrelin as a pleotrophic modulator of gonadal function and reproduction. Nat Clin Pract Endocrinol Metab. 2008;4:666-674. doi: 10.1038/ncpendmet1003.

25. Kheradmand A, Roshangar L, Taati M. The role of ghrelin on the morphometry and intracellular changes in the rat testis. Tissue Cell. 2009;41:105-111. doi: 10.1016/j.tice.2008.07.006.

26. Unniappan S. Ghrelin: an emerging player in the regulation of reproduction in non-mammalian vertebrates. Gen Comp Endocrinol. 2010;167:340-343. doi: 10.1016/j.ygcen.2009.12.003.

27. Moretti E, Vindigni C, Tripodi SA et al. Immunolocalisation of ghrelin and obestatin in human testis, seminal vesicles, prostate and spermatozoa. Andrologia. 2014;46:979-985. doi: 10.1111/and.12183.

28. Koh PO. Streptozotocin-induced diabetes increases the interaction of $\mathrm{Bad} / \mathrm{Bcl}-\mathrm{XL}$ and decreases the binding of pBad/14-3-3 in rat testis. Life Sci. 2007;81:1079-1084. doi: 10.1016/j.lfs.2007.08.017.

29. Ricci G, Catizone A, Esposito R et al. Diabetic rat testes: morphological and functional alterations. Andrologia. 2009;41:361-368. doi: 10.1111/j.1439-0272.2009.00937.x.

30. Meyer K, Deutscher J, Anil M et al. Serum androgen levels in adolescents with type 1 diabetes: relationship to pubertal stage and metabolic control. J Endocrinol Invest. 2000;23:362-368. PMID: 10908163.

31. Baker HW. Reproductive effects of nontesticular illness. Endocrinol Metab Clin North Am. 1998;27:831-850. PMID: 9922910.

32. Kanter M, Aktas C, Erboga M. Protective effects of quercetin against apoptosis and oxidative stress in streptozotocin-induced diabetic rat testis. Food Chem Toxicol. 2012;50:719-725. doi: 10.1016/j.fct.2011.11.051.
33. Sexton WJ, Jarow JP. Effect of diabetes mellitus upon male reproductive function. Urology. 1997;49:508-513. doi: 10.1016/ /S0090-4295(96)00573-0.

34. Amaral S, Mota PC, Lacerda B et al. Testicular mitochondrial alterations in untreated streptozotocin-induced diabetic rats. Mitochondrion. 2009;9:41-50. doi: 10.1016/j.mito.2008.11.005.

35. Kasturi SS, Tannir J, Brannigan RE. The metabolic syndrome and male infertility. J Androl. 2008;29:251-259. doi: 10.2164/ /jandrol.107.003731.

36. Ghafari S, Balajadeh BK, Golalipour MJ. Effect of Urtica dioica L. (Urticaceae) on testicular tissue in STZ-induced diabetic rats. Pak J Biol Sci. 2011;14:798-804. PMID: 22545354.

37. Zhang S, Zhang Q, Zhang L et al. Expression of ghrelin and leptin during the development of type 2 diabetes mellitus in a rat model. Mol Med Rep. 2013;7:223-228. doi: 10.3892/ /mmr.2012.1154.

38. Ishii S, Kamegai J, Tamura $\mathrm{H}$ et al. Role of ghrelin in streptozotocin-induced diabetic hyperphagia. Endocrinology. 2002;143:4934-4937. doi: 10.1210/en.2002-220612.

39. Martini AC, Fernandez-Fernandez R, Tovar S et al. Comparative analysis of the effects of ghrelin and unacylated ghrelin on luteinizing hormone secretion in male rats. Endocrinology. 2006;147:2374-2382. doi: 10.1210/en.2005-1422.

40. Sirotkin AV, Chrenkova M, Nitrayova S et al. Effects of chronic food restriction and treatments with leptin or ghrelin on different reproductive parameters of male rats. Peptides. 2008;29:1362-1368. doi: 10.1016/j.peptides.2008.03.011.

41. Duran C, Yonem A, Ustun I et al. Plasma ghrelin levels in males with idiopathic hypogonadotropic hypogonadism. Endocrine. 2008;34:81-86. doi: 10.1007/s12020-008-9102-x.

42. Ilhan T, Erdost H. Effects of capsaicin on testis ghrelin expression in mice. Biotech Histochem. 2013;88:10-18. doi: 10.3109/10520295.2012.724083.

43. Ishikawa T, Fujioka H, Ishimura T et al. Ghrelin expression in human testis and serum testosterone level. J Androl. 2007;28:320-324. doi: 10.2164/jandrol.106.000810.

Submitted: 16 December, 2014

Accepted after reviews: 11 March, 2015

Available as AoP: 12 March, 2015 